\title{
African Animal Trypanosomosis in an Agrarian Settlement in Kaduna City, Kaduna State, Northern Nigeria
}

\author{
Wayo B. ${ }^{*}$, Garba H.A., Mohammad B., Abdullahi R.A., \\ Kassim M. \& Sumayin H.
}

Nigeria Institute for Trypanosomiasis Research, Kaduna, Nigeria.

Article No.: 102117153

DOI: 10.15580/GJAS.2017.8.102117153

Submitted: 21/10/2017

Accepted: 25/10/2017

Published: $30 / 10 / 2017$

${ }^{*}$ Corresponding Author

Wayo $B$.

E-mail: duchiwayo@gmail.com

Keywords:

Trypanosomiasis, Trypanosomes,

Cattle, Agrarian, Kaduna, Nigeria
Trypanosomiasis has been recognized as a major cause of sickness and death throughout sub-Saharan Africa as well as a major constraint on the use of livestock. Inadequate disease reporting and surveillance has hampered the control of the disease. This study sought to investigate the prevalence of Trypanosomiasis among cattle in Gwaraji district (an agrarian settlement on the fringes of Kaduna metropolis), Igabi Local government area of Kaduna State in Northern Nigeria. A total of 94 cattle were sampled from about 30 herds. These cattle belong to Fulani herdsmen. Parasitological examination was carried out using the Standard Trypanosome Detection Method. The overall infection rate was $25.53 \%$ and the trypanosome species observed were Trypanosoma congolense $(70.83 \%)$, T. brucei $(16.66 \%)$ and mixed infections of T. brucei and $T$. congolense (12.5\%). The implication of the species identified, method of diagnosis and public health concerns were discussed. 


\section{INTRODUCTION}

It has been reported that since the dawn of the $20^{\text {th }}$ century, Trypanosomiasis (Human and Animal) has been recognized as a major cause of sickness and death throughout sub-Saharan Africa as well as a major constraint on the use of livestock (Allsop 2001). It lies at the heart of Africa's poverty with estimates of gross national per capita income showing that 20 of the world's 25 poorestcountries are affected by trypanosomiasis (Bauer et al. 2011). Although there are more prevalent human diseases (particularly diarrhoea, malaria and AIDS) and livestock diseases of similar economic importance, trypanosomiasis arguably represents the greatest debilitating limitation on agricultural productionand sustainable human livelihoods on the continent (Allsopp 2001, Hursey 2000).

It has been estimated that the control of the disease in Nigeria can potentially triple the current cattle population (Onyiah 1997). It is also estimated that about of $5-10 \%$ increase in GDP and almost $\$ 5$ billion dollars savings (from annual losses) is projected once the disease is controlled in sub-sahara Africa (Auty et al., 2015; llemobade 2009). Also, about 10 million $\mathrm{km} 2$ of the region (representing about $46 \%$ of the total land) isinfested with tsetse flies (the vector of the disease) distributed over a belt spanningbetween latitudes $158 \mathrm{~N}$ and $208 \mathrm{~S}$. 46-62 million head of cattle and other livestockspecies are at risk of contracting the disease (Simukoko et al. 2007).

Inadequate disease reporting and surveillance has hampered the control of the disease. This study sought to investigate the prevalence of Trypanosomiasis among cattle in Gwaraji district (an agrarian settlement on the fringes of Kaduna metropolis), Igabi Local government area of Kaduna State in Northern Nigeria.

\section{MATERIALS AND METHODS}

\section{Study area:}

The study was conducted in Gwaraji district, Igabi Local government area, Kaduna State, NorthWest Nigeria. The area is a suburban part of Kaduna metropolis where the main occupation of the inhabitants is farming. The cattle herders in their midst are the Fulani who engage in minimal farming activities and some migrate with their cattle in search of pasture.

Kaduna State is located on latitude $10^{\circ} \mathrm{N}$, longitude $10^{\circ} \mathrm{E}$ and altitude $616 \mathrm{~m}$ above sea level. The mean annual rainfall is between $880-1380 \mathrm{~mm}$. The area lies within the sub humid zone, which is characterized by a dry season period from November to April, and a rainy season from May to October. The vegetation consists of the typical Northern Guinea savannah woodland.

Sampling was carried out at one point $\mathrm{N} 11^{\circ} 67^{\prime} 27.5^{\prime \prime} \mathrm{E} 3^{\circ} 60^{\prime} 43.1^{\prime \prime}$ and elevation of $634 \mathrm{~m}$.

\section{Sampling and Diagnosis:}

A total of 94 cattle were sampled from about 30 herds. These cattle belong to Fulani herdsmen. Animals sampled were selected by simple random sampling.

About 3mls of blood was drawn from the jugular vein using a hypodermic needle and transferredinto an Ethylene Diamine Tetra-aceteticAcid (EDTA) sample bottle. Parasitological examination was carried out using the Standard Trypanosome Detection Method i.e Haematocrit centrifugation technique HCT (Woo, 1971), Buffy coat method BCM (Murray et al., 1977), and Giemsa stained thick \&thin films. The packed cell volume (PCV) of each animal was also determined while trypanosome species were identified based on their motility using the BCM and morphological features from Giemsa stained films.

\section{Statistical analysis:}

The data obtained from this study was analyzed using the student's t-test. A p-value of $<0.05$ orless was considered significant.

TABLE 1: Table showing Prevalence and species observed

\begin{tabular}{|l|l|l|}
\hline Index & Value & $\%$ \\
\hline Number sampled & 94 & \\
\hline Number positive & 24 & 25.53 \\
\hline Number negative & 70 & \\
\hline Trypanosome species & & 70.83 \\
\hline Trypanosoma congolense & 17 & 16.66 \\
\hline Trypanosoma brucei & 4 & 12.50 \\
\hline T. brucei/T.congolense & 3 & \\
\hline
\end{tabular}

The overall infection rate was $25.53 \%$ and the trypanosome species observed were Trypanosoma congolense $(70.83 \%)$, T. brucei $(16.66 \%)$ and mixed infections of $T$. brucei and T. congolense (12.5\%). The average packed cell volume (PCV) of infected animals (26.62) appeared higher than the average PCV of non infected (26.40). This was however statistically insignificant $(p>0.05)$.

\section{DISCUSSION}

The results are similar to earlier reports in cattle $29.2 \%$ (Samdi et al., 2012), 25.23\% (Dauda et al., 2017),37.5\% (Haruna et al., 2017) but differ from earlier reports in the region 9\% in Lere (Abenga et al.2004) or other parts of Northern Nigeria 3.8\%in Benue (Enwezor et al., 2012) $6.2 \%$ in Gombe 
(Shamaki et al., 2009) and $19.9 \%-67.6 \%$ (at different times of the year, Majekodunmi et al., 2013). Animals presented also displayed clinical signs consistent with Animal Trypanosomiasis.

The high occurrence of $T$. congolense among the Trypanosome species concurs with some previous reports (Simukoko et al., 2007, Dauda et al., 2017 and Haruna et al., 2017). But differs with others in the area where T.vivax was more prevalent (Abenga et al., 2004, Shamaki et al., 2009, Samdi et al., 2012 and Enwezor et al., 2012). The use of more sensitive diagnostic methods would have helped get more accurate results in terms of specific parasites and prevalence (Simukoko et al., 2007).

Of concern is also the observation of $T$. brucei parasites which are not distinguishable from Human Trypanosomes from this parasitological method which could be a potential public health concern (Karshima et al., 2012). Further and more widespread studies with more sensitive diagnostics are necessary. It can be established from this study that Trypanosomiasis is present in the locality and a potential threat to cattle production.

\section{REFERENCES}

Abenga J.N., F.N.C. Enwezor, F.A.G. Lawani, H.O. Osue and E.C.D. Ikemereh (2004). Trypanosome Prevalence in Cattle in Lere Area in Kaduna State, North Central Nigeria. Revue Élev. Méd. vét. Pays trop., 2004, 57 (12) : 45-48.

Allsopp R. (2001). Options for vector control against trypanosomiasis in Africa. Trends in Parasitology Vol.17 No.1 January 2001.

Auty H., S.J. Torr, T. Michoel, S. Jayaraman \& L.J. Morrison (2015).Cattle trypanosomosis: the diversity of trypanosomes and implications for disease epidemiology and control. Rev. Sci. Tech. Off. Int. Epiz., 2015, 34 (2), 587-598.

Bauer B, Holzgrefe B, Mahama Cl, Baumann MPO, Mehlitz D, et al. (2011) Managing Tsetse Transmitted Trypanosomosis by Insecticide Treated Nets anAffordable and Sustainable Method for Resource Poor Pig Farmers in Ghana. PLoS Neglected Tropical Diseases 5(10): e1343. doi:10.1371/journal.pntd.0001343.

Dauda H., Abubakar S., Muhammad A.A., Jarmai K.Y., Uzoigwe L., Allen D.O., Ahmed A.A., Ngamdu A.S.,Jega Z., *Wayo B. \& Kalejaiye J.O. (2017). Trypanosomiaisis in Non Migratory Cattle in Suburban Kaduna. Greener Journal of
Agricultural Sciences Vol. 7 (7), pp. 157-159. ISSN: 2276-

7770 ICV: 6.15.

Enwezor F.N.C., S.M. Samdi, O. ljabor \& J.N. Abenga (2012). The Prevalence of Bovine trypanosomes in parts of Benue state, North-central Nigeria. Journal of Vector Borne Diseases 49, September 2012, pp. 188-190.

Haruna M.K., Malala A.U., Wayo B., Adamu U.O., Sumayin H.M., Shettima F.T. and Kalejaiye J.O. (2017). Trypanosomiasis in a migrating herd of cattle in Kaduna state Nigeria. African Journal of Clinical and Experimental Microbiology. 18 (2): 129-131isbn 1595$689 \mathrm{x}$

Ajcem/1720http://www.ajol.info/journals/ajcemhttps://dx. doi.org/10.4314/ajcem.v18i2.12.

Hursey, B.S. (2000). PAAT: The Programme Against African Trypanosomosis. Trends in Parasitology. 2000P04 (Special Edition).

llemobade A.A. (2009). Tsetse and trypanosomosis in Africa: The challenges, the opportunities. Onderstepoort Journal of Veterinary Research, 76:35-40.

Majekodunmi A.O., Fajinmi A., Dongkum C., Picozzi K., Thrusfield M.V. and Welburn S.C. (2013). A longitudinal survey of African animal trypanosomiasis in domestic cattle on the Jos Plateau, Nigeria: prevalence, distribution and risk factors. Parasites \& Vectors 2013, 6:239 http://www.parasitesandvectors.com/content/6/1/239.

Murray M., P.K. Murray and W.I.M. Mclntyre (1977). An improved Parasitological technique for the diagnosis of African Trypanosomiasis. Transactions of the Royal Society of Tropical Medicine and Hygiene. 71; 325-326.

Onyiah J.A. (1997). African animal trypanosomiasis: An overview of the current status in Nigeria. Tropical Veterinarian. 15: 111- 116.

Samdi S.M., B. Bello, A. Abubakar, R.L. Bizi, K. David, Haruna M.K., Abdullahi R.A., Muhammad H.and JibrilH.Z. (2012). Human Behavior in the Epidemiology and Control of African Trypanosomosis in Kachia Local Government Area of Kaduna State, Nigeria. International Journal of Animal and Veterinary Advances 4(5): 312-315, 2012ISSN: 2041-2908.

Shamaki, B.U., Obaloto, O.B., Kalejaiye, J.O., Lawani, F.A.G., Balak, G.G. and Charles D. (2009). A Wet Season Survey of Animal Trypanosomosis in Shongom Local government area of Gombe state, Nigeria. Journal of Protozoological Research 19, 1-6.

Simukoko H., T. Marcotty , I. Phiri , D. Geysen , J. Vercruysse, P. Van den Bossche (2007). The comparative role of cattle, goats and pigs in the epidemiology of livestock trypanosomiasis on the plateau of eastern Zambia Veterinary Parasitology 147: 231-238.

Woo P.T.K. (1971). Evaluation of Hematocrit centrifuge and other techniques for field diagnosis of Trypanosomiasis and Filariasis. Acta Tropica 28;298-303. 